\title{
Financial Performance Analysis of Bank Companies Before and After the Fintech Era
}

\author{
Syena Idfilandu, Saripudin \\ Perbanas Institute \\ Jakarta Selatan, Indonesia
}

\begin{abstract}
Abstrak
Tujuan penelitian ini adalah untuk menganalisis dan mendapatkan bukti empiris perbandingan kinerja keuangan perusahaan perbankan sebelum dan sesudah era fintech. Data yang digunakan dalam penelitian ini meliputi Rasio Likuiditas: Loan to Asset Ratio (LAR) dan Loan to Deposit Ratio (LDR), Rasio Solvabilitas: Debt to Asset Ratio (DAR) dan Debt to Equity Ratio (DER), dan Rasio Rentabilitas: Return on Asset (ROA), Return on Equity (ROE), dan Return on Invested Capital (ROIC) periode 2013 s.d. 2015 dan 2017 s.d. 2019. Hasil penelitian dalam studi ini menemukan bahwa terdapat perbedaan yang signifikan antara rasio Likuiditas (LAR dan LDR), rasio Solvabilitas (DAR dan DER), dan rasio Rentabilitas (ROA, ROE, dan ROIC) pada perusahaan perbankan yang terdaftar di Bursa Efek Indonesia sebelum dan sesudah adanya fintech. Artinya, dengan kehadiran fintech mempengaruhi kinerja keuangan perusahaan bank dilihat dari variabel-variabel tersebut.
\end{abstract}

\begin{abstract}
The purpose of this study is to analyze and obtain empirical evidence of comparative financial performance of banking companies before and after the fintech era. The data used in this study include the Liquidity Ratio: Loan to Asset Ratio (LAR) and the Loan to Deposit Ratio (LDR), the Solvability Ratio: Debt to Asset Ratio (DAR) and the Debt to Equity Ratio (DER), and the Rentability Rato: Return on Asset Ratio (ROA), Return on Equity (ROE), and Return on Invested Capital (ROIC) for the period 2013 to 2015 and 2017 to 2019. The results of this study found that there are significant differences between the liquidity ratios (LAR and LDR), solvency ratios (DAR and DER), and profitability ratios (ROA, ROE, and ROIC) in bank companies listed on the Indonesia Stock Exchange before and after fintech. It means that the presence of fintech affects banks financial performance as seen from these variables.
\end{abstract}

https://journals.telkomuniversity.ac.id/jaf

E-ISSN 2581-1088 


\section{PENDAHULUAN}

Di era globalisasi saat ini, persaingan lembaga keuangan di Indonesia semakin ketat. Oleh karena itu, setiap unsur lembaga keuangan dituntut untuk meningkatkan kualitas layanan kepada nasabah. Seluruh jenis lembaga keuangan yang ada di Indonesia terus melakukan inovasi demi beradaptasi di era teknologi. Menurut Christensen dkk. (2015), inovasi disruptif yang ditimbulkan akiat hadirnya perusahaan startup dapat menganggu keberadaan perusahaan incumbent. Inovasi disruptif ini biasanya mengambil segmen pasar tertentu yang kurang diminati atau dianggap kurang penting bagi penguasa pasar, namun inovasinya bersifat breakthrough dan mampu meredefinisi sistem atau pasar yang eksisting (Hadad, 2017).

Menurut Gitman dkk (2011), lembaga keuangan adalah lembaga yang memberi fasilitas produk keuangan serta memutar arus uang dalam perekonomian, memiliki kegiatan operasional dasar yaitu menghimpun dana dari masyarakat dan menyalurkannya kembali kepada masyarakat yang membutuhkan. Lembaga keuangan memerlukan adaptasi yang cepat terhadap teknologi, seiring berkembangnya fintech di Indonesia. Kehadiran layanan keuangan berbasis teknologi di Indonesia telah menjadi keniscayaan sejalan dengan perkembangan teknologi informasi dan komunikasi. Fintech mengacu pada setiap jenis teknologi yang memungkinkan solusi di sisi ekonomi keuangan (Arner, Barberis dan Buckley, 2015).

Beberapa studi empiris seperti Beck dkk. (2007) dan Bruhn dkk. (2009) menjelaskan bahwa melalui pembangunan pada sektor keuangan menjadi instrumen penting dalam angka pemerataan dan reduksi kemiskinan yang dapat ditunjukkan melalui peningkatan akses dan layanan keuangan. Kajian empiris yang terkait fintech dan inklusi keuangan juga dilakukan oleh Gabor dan Brooks (2016) yang memaparkan pentingnya peranan layanan dan akses keuangan berbasis fintech sebagai bentuk dari intervensi pembangunan keuangan.

Penelitian yang dilakukan oleh Nizar (2017) menyatakan bahwa terjadinya evolusi global dalam inovasi teknologi keuangan juga turut mempengaruhi perkembangan fintech di Indonesia. Hanya saja indikator yang tersedia dan dapat digunakan untuk melihat konfigurasi fintech di Indonesia saat ini masih sangat terbatas. Berdasarkan data yang tersedia, hanya jumlah perusahaan dan market size yang dapat dijadikan sebagai referensi untuk menjelaskan konfigurasi tersebut.

Dari sisi jumlah perusahaan, perkembangan yang spektakuler terjadi dalam tahun 2015 s.d. 2016, dimana jumlah perusahaan fintech bertambah sebanyak 125 perusahaan hingga menjadi 165 perusahaan. Artinya terjadi peningkatan jumlah perusahaan fintech sekitar 312,5\% dibandingkan tahun sebelumnya.

Dengan bertambahnya jumlah perusahaan dan jenis model pembiayaan alternatif (fintech) yang tersedia, tahun 2016 merupakan tahun yang istimewa bagi aktivitas fintech di Indonesia dengan focal point terjadinya ekspansi yang pesat di pasar pembiayaan online. Dalam periode 2013 s.d. 2015, market size jasa layanan fintech tumbuh modest sekitar 24,2\% rata-rata per tahun. Pada tahun 2016 menjadi titik balik bagi kegiatan pembiayaan alternatif dengan total nilai pembiayaan mencapai US\$35,35 juta atau setara dengan Rp470,6 miliar. Artinya terjadi kenaikan yang sangat substansial dibandingkan tahun 2015 yang hanya mencapai US\$2,26 juta (setara dengan Rp30,3 miliar) atau tumbuh dengan laju lebih dari 1.464\%. (Nizar, 2017).

https://journals.telkomuniversity.ac.id/jaf

E-ISSN 2581-1088 
Journal Accounting and Finance

Edisi Vol. 5, No. 2, September 2021

Universitas Telkom

\section{PENGEMBANGAN HIPOTESIS}

Hipotesis merupakan sesuatu yang dapat digunakan untuk menjelaskan hubungan antara variabelvariabel yang diuji dalam penelitian, yang bersifat sementara, bersifat dugaan, dan belum kuat (Anshori, 2009).

\section{A. Fintech}

Financial Technology (juga disebut sebagai fintech), merupakan model layanan keuangan baru yang dikembangkan melalui inovasi teknologi informasi (Hsueh, 2017). Layanan fintech menghasilkan peningkatan inklusi layanan keuangan dan juga suatu pengalaman baru dalam hal efisiensi biaya. Hal-hal tersebut menjadi daya tarik fintech, dimana kehadirannya memberikan solusi yang sangat terfokus dan memberikan pengalaman yang lebih personal kepada pelanggan dalam memanfaatkan teknologi digital (Rizvi, dkk. 2018). Fintech biasanya tidak independen dari bank, tetapi telah berkembang dalam usaha patungan atau jenis aliansi lain dengan bank tradisional. (Boot, 2017)

Aturan mengenai fintech lebih lanjut diatur dalam Peraturan OJK Nomor 13/POJK.02/2018 tentang Inovasi Keuangan Digital (IKD). (Ansori, 2019)

\section{B. Kinerja Keuangan Bank}

Bank adalah suatu jenis lembaga keuangan yang melaksanakan berbagai macam jasa, seperti memberikan pinjaman, mengedarkan mata uang, pengawasan terhadap mata uang, bertindak sebagai tempat penyimpanan benda-benda berharga, membiayai perusahaan-perusahaan, dan lainlain (Abdurrachman, 2007).

Kinerja keuangan dapat diukur dengan menggunakan analisis rasio keuangan. Dengan analisis rasio keuangan ini dapat diketahui kekuatan dan kelemahan suatu perusahaan. Dendawijaya (2009) menyebutkan bahwa dalam menganalisis kinerja bank perlu diperhatikan rasio-rasio keuangan antara lain analisis rasio likuiditas, analisis rasio rentabilitas dan analisis rasio solvabilitas.

\section{Likuiditas}

Menurut Ashari, dkk. (2020), dalam rasio likuiditas rasio yang dapat diukur antara lain: Loan to Asset Ratio (LAR), dan Loan to Deposit Ratio (LDR). Loan to Asset Ratio (LAR) adalah rasio yang digunakan untuk mengukur tingkat likuiditas bank dalam memenuhi kredit yang diajukan dengan menggunakan total aset yang dimiliki bank (Iman, 2018). Loan to Deposit Ratio (LDR) merupakan rasio untuk mengukur komposisi jumlah kredit yang diberikan dibandingkan dengan jumlah dana masyarakat dan modal sendiri yang digunakan (Kasmir, 2012). LDR merupakan rasio keuangan perusahaan perbankan yang digunakan untuk mengukur perbandingan antara kredit yang diberikan pada masyarakat dengan dana yang diterima bank seperti giro, tabungan, deposito dan kewajiban jangka pendek lainnya (Km. Suli Astrini, I Wayan Suwendra, dan I Ketut Suwarna, 2018).

https://journals.telkomuniversity.ac.id/jaf

E-ISSN 2581-1088 


\section{Solvabilitas}

Menurut Kasmir (2010), rasio solvabilitas atau leverage ratio merupakan rasio yang digunakan untuk mengukur sejauh mana aktiva perusahaan dibiayai dengan utang. Rasio solvabilitas terdiri dari rasio hutang terhadap total aktiva (Debt to Assets Ratio), rasio hutang terhadap ekuitas (Debt to Equity Ratio). Debt to Assets Ratio (DAR) digunakan untuk mengukur seberapa jauh nilai seluruh aktiva bank dibiayai atau dananya diperoleh dari sumber-sumber hutang. Debt to Equity Ratio (DER) merupakan rasio yang digunakan untuk mengukur kemampuan bank dalam menutup sebagian atau seluruh hutang-hutangnya, baik jangka panjang maupun jangka pendek dengan dana yang berasal dari modal sendiri atau modal inti (Iman, 2018).

\section{E. Rentabilitas}

Rentabilitas ekonomi adalah perbandingan antara laba bersih sesudah pajak dengan total aktiva yang dipergunakan untuk menghasilkan laba tersebut dan dinyatakan dalam persentase (Danang, 2013). Menurut Dendawijaya (2009) rasio rentabilitas adalah rasio yang menunjukkan tingkat efisiensi usaha dan profitabilitas yang dicapai oleh bank yang bersangkutan. Rasio ini dapat pula digunakan untuk mengukur tingkat kesehatan bank. Return on Assets (ROA) digunakan untuk mengukur kemampuan manajemen bank dalam memperoleh keuntungan secara keseluruhan. ROA diperoleh dengan membandingkan laba dengan total aset yang dimiliki bank pada periode tertentu. ROE adalah rasio yang digunakan untuk mengukur kemampuan perusahan dalam menghasilkan laba bersih dari modal sendiri yang digunakan oleh perusahaan tersebut atau perbandingan antara jumlah laba yang tersedia bagi pemilik modal sendiri atau disatu pihak dengan jumlah modal sendiri yang menghasilkan laba tersebut dilain pihak. Return on Invested Capital (ROIC) dihitung sebagai rasio anatara laba tahun berjalan dan jumlah modal yang diinvestasikan pada tahun sebelumnya (Subramanyam, 2014).

\section{F. Hipotesis Penelitian}

Dalam penelitian ini, ditentukan hipotesis yaitu:

\section{Likuiditas}

H1 (a): Terdapat perbedaan kinerja keuangan yang didasarkan pada rasio (Likuiditas Loan to Asset Ratio / LAR) pada perusahaan perbankan yang terdaftar di Bursa Efek Indonesia sebelum dan sesudah adanya fintech.

H1 (b): Terdapat perbedaan kinerja keuangan yang didasarkan pada rasio (Likuiditas Loan to Deposit Ratio / LDR) pada perusahaan perbankan yang terdaftar di Bursa Efek Indonesia sebelum dan sesudah adanya fintech.

\section{Solvabilitas}

https://journals.telkomuniversity.ac.id/jaf

E-ISSN 2581-1088 
H2 (a): Terdapat perbedaan kinerja keuangan yang didasarkan pada rasio (Solvabilitas Debt to Asset Ratio / DAR) pada perusahaan perbankan yang terdaftar di Bursa Efek Indonesia sebelum dan sesudah adanya fintech.

H2 (b): Terdapat perbedaan kinerja keuangan yang didasarkan pada rasio (Solvabilitas Debt to Equity Ratio / DER) pada perusahaan perbankan yang terdaftar di Bursa Efek Indonesia sebelum dan sesudah adanya fintech.

\section{Rentabilitas}

H3 (a): Terdapat perbedaan kinerja keuangan yang didasarkan pada rasio (Rentabilitas Return on Asset / ROA) pada perusahaan perbankan yang terdaftar di Bursa Efek Indonesia sebelum dan sesudah adanya fintech.

H3 (b): Terdapat perbedaan kinerja keuangan yang didasarkan pada rasio (Rentabilitas Return on Equity / ROE) pada perusahaan perbankan yang terdaftar di Bursa Efek Indonesia sebelum dan sesudah adanya fintech.

H3 (c): Terdapat perbedaan kinerja keuangan yang didasarkan pada rasio (Rentabilitas Return on Invested Capital / ROIC) pada perusahaan perbankan yang terdaftar di Bursa Efek Indonesia sebelum dan sesudah adanya fintech.

\section{METODE, DATA DAN ANALISIS}

Dalam penelitian ini, penulis menggunakan jenis penelitian kuantitatif untuk mengetahui apakah terdapat perbedaan kinerja keuangan perusahaan yang tercermin dari rasio Likuiditas (LAR dan LDR), Solvabilitas (DAR dan DER), dan Rentabilitas (ROA, ROE, dan ROIC) pada perusahaan perbankan yang terdaftar di Bursa Efek Indonesia sebelum dan sesudah era Fintech.

Desain penelitian adalah rencana atau rancangan yang dibuat oleh peneliti, sebagai acuan kegiatan yang akan dilaksanakan (Arikunto, 2010). Pada penelitian ini, teknik pengambilan sampel dilakukan dengan menggunakan metode nonprobability sampling. Sampel yang diambil untuk penelitian ini adalah 35 (tiga puluh lima) perusahaan perbankan konvensional (Bank Umum BUMN, Bank Umum Swasta Nasional, dan Bank Pembangunan Daerah) di Indonesia yang secara resmi terdaftar di Otoritas Jasa Keuangan per Desember 2019 dan terdaftar aktif dalam Bursa Efek Indonesia pada 2013 s.d. 2019, serta telah melaporkan keuangan secara lengkap pada periode tahun 2013 s.d. 2015 dan 2017 s.d. 2019.

Sumber data pada penelitian ini diperoleh dari data sekunder, yaitu data yang diperoleh secara tidak langsung atau melalui media perantara. Data yang diperoleh dalam penelitian ini antara lain data Neraca Keuangan, Laporan Laba dan Rugi, Laporan Arus Kas, dan Rasio Keuangan: Likuiditas (LAR dan LDR), Solvabilitas (DAR dan DER), serta Rentabilitas (ROA, ROE, dan ROIC). Data yang dibutuhkan adalah data masing-masing variabel rasio keuangan. Variabel LAR, LDR, DAR, DER, ROA, ROE, ROIC diukur dengan cara menghitung rata-rata rasio untuk periode tiga tahun sebelum adanya fintech (tahun 2013 s.d. 2015) dan 3 tahun setelah adanya fintech (tahun 2017 s.d. 2019).

https://journals.telkomuniversity.ac.id/jaf

E-ISSN 2581-1088 
Tahun 2016 digunakan sebagai pemisah / event window dalam pengukuran, mengingat jumlah perusahaan fintech dan market size yang naik secara signifikan pada tahun bersangkutan (Nizar, 2017). Peningkatan tersebut terjadi dalam tahun 2015 s.d. 2016, dimana jumlah perusahaan fintech bertambah sebanyak 125 perusahaan hingga menjadi 165 perusahaan. Artinya terjadi peningkatan jumlah perusahaan fintech sekitar $312,5 \%$ dibandingkan tahun sebelumnya, sebagaimana terlihat pada tabel berikut:

\section{Profil Jumlah Perusahaan Fintech di Indonesia}

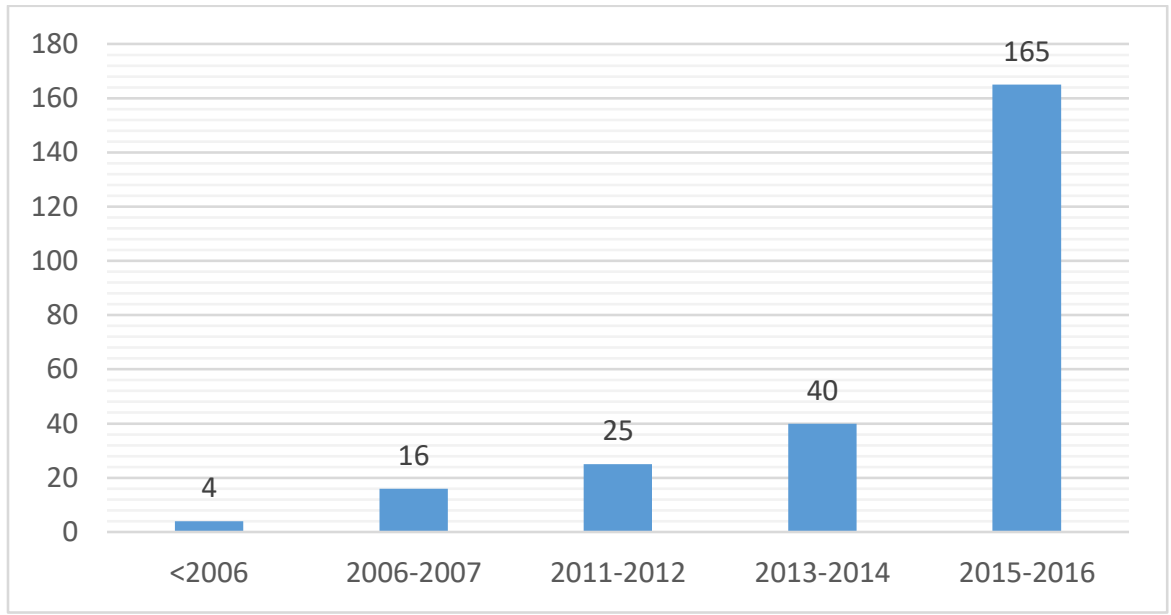

Sumber: Asosiasi Fintech Indonesia dan OJK (2017)

Menurut Garvey, K. dkk. (2017), sepanjang tahun 2016 di Indonesia dijumpai 9 jenis model pembiayaan alternatif online yaitu: (i) Peer-to-peer (P2P)/market place business lending; (ii) Peerto-peer (P2P)/market place consumer lending; (iii) Peer-to-peer (P2P)/market place real estate lending; (iv) Donation-based crowdfunding; (v) Equity-based crowdfunding; (vi) Reward-based crowdfunding; (vii) Revenue-sharing/profit sharing crowdfunding; (viii) Debentures (debt-based securities); dan (ix) Balance sheet consumer lending. Dari Sembilan jenis model tersebut 6 (enam) model diantaranya mulai diperkenalkan dalam tahun 2016 dan 3 model lainnya sudah tersedia sejak tahun 2013.

\section{A. Uji Normalitas}

Uji normalitas dilakukan untuk melihat apakah variabel-variabel pada penelitian terdistribusi normal atau tidak. Hasil uji normalitas digunakan untuk melakukan pemilihan uji statistik yang akan digunakan. Model penelitian parametrik mengharuskan data yang terdistribusi normal, sedangkan apabila data tidak terdistribusi normal, maka penelitian menggunakan uji non parametrik.

Pada penelitian ini, hasil Uji Normalitas didapatkan melalui Uji Shapiro Wilk dengan melihat tingkat signifikansi dibandingkan dengan tabel Shapiro Wilk. Penghitungan Uji Shapiro Wilk dapat dilihat dalam rumus sebagai berikut:

https://journals.telkomuniversity.ac.id/jaf

E-ISSN 2581-1088 


$$
\begin{gathered}
T_{3}=\frac{1}{D}\left[\sum_{i=1}^{k} a_{i}\left(X_{n-i+1}-X_{i}\right)\right]^{2} \\
D=\sum_{i=1}^{n}\left(X_{i}-\bar{X}\right)^{2}
\end{gathered}
$$

Keterangan:

$\mathrm{D} \quad=$ Koefisien tes Shapiro Wilk

$\mathrm{X}_{\mathrm{n}-i+1}=$ Angka ke $\mathrm{n}-i+1$ pada data

$\mathrm{Xi} \quad=$ Angka ke $i$ pada data

Hasil dari nilai $\mathrm{T}_{3}$ selanjutnya dibandingkan dengan nilai tabel Shapiro Wilk untuk menentukan posisi nilai probabilitas. Interpretasi dapat dilakukan dengan membandingkan nilai signifikansi dengan nilai alfa $(\alpha=5 \%)$ sebagai berikut:

1. Jika nilai signifikansi (sig.) $>\alpha$, maka $\mathrm{H}_{0}$ diterima dan $\mathrm{H}_{\mathrm{a}}$ ditolak. Data berdistribusi normal.

2. Jika nilai signifikansi (sig.) $<\alpha$, maka $\mathrm{H}_{0}$ ditolak dan $\mathrm{H}_{a}$ diterima. Data tidak berdistribusi normal.

\section{B. Uji Hipotesis}

Hasil dari uji normalitas digunakan untuk menentukan alat uji yang tepat dalam pengujian hipotesis. Apabila berdasarkan uji normalitas diketahui bahwa data terdistribusi normal, maka statistik uji yang digunakan untuk melakukan uji hipotesis adalah Paired Sample T-Test. Apabila data tidak terdistribusi normal, maka uji hipotesis yang digunakan adalah Wilcoxon Signed Rank Test.

Dalam melakukan uji hipotesis dengan Paired Sample T-Test, dengan nilai $\alpha=5 \%$ atau 0,05, syarat agar hipotesis diterima adalah dengan melihat nilai signifikansi 2-tailed. Pedoman dalam pengambilan keputusan dalam uji Paired Sample T-Test, yaitu:

1. Jika nilai signifikansi (sig. 2-tailed) $>\alpha$, maka $\mathrm{H}_{0}$ diterima dan $\mathrm{H}_{\mathrm{a}}$ ditolak.

2. Jika nilai signifikansi (sig. 2-tailed) $<\alpha$, maka $\mathrm{H}_{0}$ ditolak dan $\mathrm{H}_{\mathrm{a}}$ diterima.

Berdasarkan hal tersebut, apabila nilai signifikansi (2-tailed) $<0,05$, artinya terdapat perbedaan yang signifikan pada kinerja keuangan (Rasio Likuiditas / Solvabilitas / Rentabilitas) perusahaan perbankan sebelum dan sesudah era fintech. Sebaliknya, apabila nilai signifikansi (2tailed) $>0,05$, artinya tidak terdapat perbedaan yang signifikan pada kinerja keuangan (Rasio Likuiditas / Solvabilitas / Rentabilitas) perusahaan perbankan sebelum dan sesudah era fintech.

Selanjutnya, apabila berdasarkan hasil uji normalitas data tidak terdistribusi normal, maka uji hipotesis yang digunakan adalah Wilcoxon Signed Rank Test. Pedoman pengambilan keputusan dalam uji Wilcoxon Signed Rank Test, yaitu:

1. Jika nilai signifikansi (asymp sig. 2-tailed) $>\alpha$, maka $\mathrm{H}_{0}$ diterima dan $\mathrm{H}_{\mathrm{a}}$ ditolak.

2. Jika nilai signifikansi (asymp sig. 2-tailed) $<\alpha$, maka $\mathrm{H}_{0}$ ditolak dan $\mathrm{H}_{\mathrm{a}}$ diterima.

Berdasarkan hal tersebut, apabila nilai asymp. Sig. (2-tailed) $<0,05$, artinya terdapat perbedaan yang signifikan pada kinerja keuangan (Rasio Likuiditas / Solvabilitas / Rentabilitas)

https://journals.telkomuniversity.ac.id/jaf

E-ISSN 2581-1088 
perusahaan perbankan sebelum dan sesudah era fintech. Sebaliknya, apabila nilai asymp. sig. 2tailed $>0,05$, artinya tidak terdapat perbedaan yang signifikan pada kinerja keuangan (Rasio Likuiditas / Solvabilitas / Rentabilitas) perusahaan perbankan sebelum dan sesudah era fintech.

\section{HASIL DAN DISKUSI}

\section{A. Perbedaan rasio (Likuiditas Loan to Asset Ratio) pada perusahaan perbankan yang terdaftar di Bursa Efek Indonesia sebelum dan sesudah era fintech.}

Hasil penelitian menunjukkan angka rata-rata rasio Likuiditas Loan to Asset Ratio sebesar 13,17 sebelum era fintech meningkat menjadi 19,19 sesudah era fintech. Hal ini mengindikasikan bahwa terdapat perbedaan yang signifikan pada likuiditas LAR perusahaan perbankan sebelum dan sesudah era fintech. Loan to Asset Ratio membandingkan jumlah pinjaman yang diberikan bank, dibandingkan dengan total asset yang dimiliki bank. Peningkatan LAR dapat terjadi karena jumlah pinjaman yang meningkat atau aset perusahaan perbankan yang menurun. Dengan adanya fintech, kinerja bank dalam memberikan layanan pinjaman secara umum tetap dapat berjalan secara optimal. Di sisi lain, bank mulai berusaha untuk mengurangi jumlah aset yang dimiliki. Untuk beradaptasi dengan perkembangan teknologi, bank mulai menyadari pentingnya efisiensi dengan melakukan pengurangan aset, salah satunya dengan cara pengurangan jumlah kantor cabang.

\section{B. Perbedaan rasio (Likuiditas Loan to Deposit Ratio) pada perusahaan perbankan yang terdaftar di Bursa Efek Indonesia sebelum dan sesudah era fintech.}

Hasil penelitian menunjukkan angka rata-rata rasio Likuiditas Loan to Deposit Ratio sebesar 18,20 sebelum era fintech menurun menjadi 17,50 sesudah era fintech. Hal ini mengindikasikan bahwa terdapat perbedaan yang signifikan pada likuiditas LDR perusahaan perbankan sebelum dan sesudah era fintech. Loan to Deposit Ratio membandingkan jumlah pinjaman yang diberikan bank, dibandingkan dengan total deposit yang dimiliki bank. Penurunan LDR dapat terjadi karena jumlah pinjaman yang menurun atau deposit perusahaan perbankan yang meningkat. Apabila jumlah layanan pinjaman tetap meningkat, maka penurunan LDR dipengaruhi oleh kenaikan deposit / dana pihak ketiga.

\section{Perbedaan rasio (Solvabilitas Debt to Asset Ratio) pada perusahaan perbankan yang terdaftar di Bursa Efek Indonesia sebelum dan sesudah era fintech.}

Hasil penelitian menunjukkan angka rata-rata rasio Solvabilitas Debt to Asset Ratio sebesar 14,00 sebelum era fintech meningkat menjadi 15,73 sesudah era fintech. Hal ini mengindikasikan bahwa terdapat perbedaan yang signifikan pada solvabilitas DAR perusahaan perbankan sebelum dan sesudah era fintech Debt to Asset Ratio membandingkan jumlah hutang bank yang perlu dibayarkan oleh bank, dibandingkan dengan total asset yang dimiliki bank. Peningkatan DAR dapat terjadi karena jumlah hutang yang meningkat atau asset perusahaan perbankan yang menurun. Dilihat dari adanya kenaikan rata-rata DER, artinya dengan adanya fintech, kemampuan

https://journals.telkomuniversity.ac.id/jaf 
Journal Accounting and Finance

Edisi Vol. 5, No. 2, September 2021

Universitas Telkom

solvabilitas bank dalam membayar kembali hutang dari asset yang dimiliki pinjaman secara umum semakin rendah.

\section{Perbedaan rasio (Solvabilitas Debt to Equity Ratio) pada perusahaan perbankan yang terdaftar di Bursa Efek Indonesia sebelum dan sesudah era fintech.}

Hasil penelitian menunjukkan angka rata-rata rasio Solvabilitas Debt to Equity Ratio sebesar 15,50 sebelum era fintech meningkat menjadi 18,52 sesudah era fintech. Hal ini mengindikasikan bahwa terdapat perbedaan yang signifikan pada Solvabilitas DER perusahaan perbankan sebelum dan sesudah era fintech. Debt to Equity Ratio membandingkan jumlah hutang yang diberikan bank, dibandingkan dengan total ekuitas yang dimiliki bank. DER mencerminkan seberapa besar solvabilitas bank, apakah asset yang dimiliki cenderung lebih banyak dibiayai oleh hutang atau modal. Peningkatan DER dapat terjadi karena jumlah hutang yang meningkat atau ekuitas perusahaan perbankan yang menurun.

\section{E. Perbedaan rasio (Rentabilitas Return on Asset) pada perusahaan perbankan yang terdaftar di Bursa Efek Indonesia sebelum dan sesudah era fintech.}

Hasil penelitian menunjukkan angka rata-rata rasio Rentabilitas Return on Asset sebesar 13,00 sebelum era fintech meningkat menjadi 20,61 sesudah era fintech. Hal ini mengindikasikan bahwa terdapat perbedaan yang signifikan pada rentabilitas ROA perusahaan perbankan sebelum dan sesudah era fintech. Return on Asset membandingkan jumlah laba bersih yang diperoleh bank, dibandingkan dengan total asset yang dimiliki bank. Hal ini mencerminkan seberapa efektif Perusahaan Perbankan mampu memperoleh laba dari total asset yang dimiliki. Peningkatan ROA dapat terjadi karena jumlah laba bersih yang meningkat atau asset perusahaan perbankan yang menurun.

\section{F. Perbedaan rasio (Rentabilitas Return On Equity) pada perusahaan perbankan yang terdaftar di Bursa Efek Indonesia sebelum dan sesudah era fintech.}

Hasil penelitian menunjukkan angka rata-rata rasio Rentabilitas Return On Equity sebesar $10,43 \%$ sebelum era fintech meningkat menjadi 19,89\% sesudah era fintech. Hal ini mengindikasikan bahwa terdapat perbedaan yang signifikan pada rentabilitas ROE perusahaan perbankan sebelum dan sesudah era fintech. Return on Equity membandingkan jumlah laba bersih yang diperoleh bank, dibandingkan dengan total ekuitas yang dimiliki bank. Hal ini mencerminkan seberapa efektif Perusahaan Perbankan mampu memperoleh laba dari total modal yang dimiliki. Peningkatan ROE dapat terjadi karena jumlah laba bersih yang meningkat.

\section{G. Perbedaan rasio (Rentabilitas Return On Invested Capital) pada perusahaan perbankan yang terdaftar di Bursa Efek Indonesia sebelum dan sesudah era fintech.}

Hasil penelitian menunjukkan angka rata-rata rasio Rentabilitas Return On Invested Capital sebesar 0,9463 sebelum era fintech meningkat menjadi 1,6009 sesudah era fintech. Hal ini

https://journals.telkomuniversity.ac.id/jaf 
mengindikasikan bahwa terdapat perbedaan yang signifikan pada rentabilitas ROIC perusahaan perbankan sebelum dan sesudah era fintech. Return on Invested Capital membandingkan jumlah laba bersih setelah pajak, dibandingkan dengan investasi modal. Hal ini mencerminkan seberapa efektif Perusahaan Perbankan mampu memperoleh laba bersih dari total investasi modal yang dimiliki perusahaan. Peningkatan ROIC dapat terjadi karena jumlah laba operasional yang meningkat.

\section{KESIMPULAN DAN KETERBATASAN}

\section{A. Kesimpulan}

Berdasarkan hasil analisis yang dilakukan pada kinerja keuangan perusahaan perbankan yang terdaftar di Bursa Efek Indonesia sebelum dan sesudah era fintech, maka dapat diambil simpulan sebagai berikut:

1. Terdapat perbedaan rasio (Likuiditas Loan to Asset Ratio) pada perusahaan perbankan yang terdaftar di Bursa Efek Indonesia sebelum dan sesudah era fintech. Hal ini mengindikasikan bahwa kinerja keuangan yang didasarkan pada rasio likuiditas Loan to Asset Ratio mengalami pengaruh akibat adanya fintech.

2. Terdapat perbedaan rasio (Likuiditas Loan to Deposit Ratio) pada perusahaan perbankan yang terdaftar di Bursa Efek Indonesia sebelum dan sesudah era fintech. Hal ini mengindikasikan bahwa kinerja keuangan yang didasarkan pada rasio likuiditas Loan to Deposit Ratio mengalami pengaruh akibat adanya fintech.

3. Terdapat perbedaan rasio (Solvabilitas Debt to Asset Ratio) pada perusahaan perbankan yang terdaftar di Bursa Efek Indonesia sebelum dan sesudah era fintech. Hal ini mengindikasikan bahwa kinerja keuangan yang didasarkan pada rasio solvabilitas Debt to Asset Ratio mengalami pengaruh akibat adanya fintech.

4. Terdapat perbedaan rasio (Solvabilitas Debt to Equity Ratio) pada perusahaan perbankan yang terdaftar di Bursa Efek Indonesia sebelum dan sesudah era fintech. Hal ini mengindikasikan bahwa kinerja keuangan yang didasarkan pada rasio solvabilitas Debt to Equity Ratio mengalami pengaruh akibat adanya fintech.

5. Terdapat perbedaan rasio (Rentabilitas Return on Asset) pada perusahaan perbankan yang terdaftar di Bursa Efek Indonesia sebelum dan sesudah era fintech. Hal ini mengindikasikan bahwa kinerja keuangan yang didasarkan pada rasio rentabilitas Return on Asset mengalami pengaruh akibat adanya fintech.

6. Terdapat perbedaan rasio (Rentabilitas Return On Equity) pada perusahaan perbankan yang terdaftar di Bursa Efek Indonesia sebelum dan sesudah era fintech. Hal ini mengindikasikan bahwa kinerja keuangan yang didasarkan pada rasio rentabilitas Return On Equity mengalami pengaruh akibat adanya fintech.

7. Terdapat perbedaan rasio (Rentabilitas Return On Invested Capital) pada perusahaan perbankan yang terdaftar di Bursa Efek Indonesia sebelum dan sesudah era fintech. Hal ini mengindikasikan bahwa kinerja keuangan yang didasarkan pada rasio rentabilitas Return On Invested Capital mengalami pengaruh akibat adanya fintech.

https://journals.telkomuniversity.ac.id/jaf

E-ISSN 2581-1088 
Journal Accounting and Finance

Edisi Vol. 5, No. 2, September 2021

Universitas Telkom

\section{B. Keterbatasan}

Penelitian ini memiliki keterbatasan dan kelemahan yang perlu disempurnakan dan perlu menjadi perhatian pada penelitian selanjutnya. Keterbatasan tersebut antara lain:

1. Penggunaan variabel dalam penelitian ini terbatas pada tujuh variabel, yaitu rasio: Likuiditas Loan to Asset Ratio (LAR), Likuiditas Loan to Deposit Ratio (LDR), Solvabilitas Debt to Asset Ratio (DAR), Solvabilitas Debt to Equity Ratio (DER), Rentabilitas Return on Asset (ROA), Rentabilitas Return on Equity (ROE), dan Rentabilitas Return on Invested Capital (ROIC).

2. Penelitian ini hanya difokuskan pada perusahaan perbankan konvensional saja. Sedangkan untuk perbankan syariah belum terdapat dalam penelitian ini.

3. Penelitian ini hanya mengambil rentang waktu selama periode tahun 2013 s.d. 2015 dan 2017 s.d. 2019.

\section{DAFTAR PUSTAKA}

A. Abdurrachman. (2007). Ensiklopedia Ekonomi Keuangan dan Perdagangan. Jakarta: Pradnya Paramita.

Anggreini, Silvia Ika. (2019). The Disruption of Fintech on Rural Bank: an Empirical Study on Rural Banks in Indonesia. Yogyakarta: Universitas Islam Indonesia.

Anshori, Muslich dan Sri Iswati. (2009). Metodologi Penelitian Kuantitatif. Surabaya: Universitas Airlangga.

Ansori, Miswan. (2019). Perkembangan dan Dampak Financial Technology (Fintech) Terhadap Industri Keuangan Syariah di Jawa Tengah. Jepara: Universitas Islam Nahdlatul Ulama.

Arikunto, S. (2010). Prosedur Penelitian Suatu Pendekatan Praktik. Jakarta: Rineka Cipta.

Arner, D.W., J.N. Barberis dan R.P. Buckley. (2015). The Evolution of Fintech: A New Post-Crisis Paradigm?. Hong Kong: University of Hong Kong.

Ashari, Hasan dan Trinandari Prasetyo Nugrahanti. (2020). Analisis Kesiapan Bank Perkreditan Rakyat (BPR) Menghadapi Era Industri 4.0. Jurnal Riset Akuntansi dan Keuangan ABFI Perbanas Institute.

Ashari, Lina. (2018). Analisis Profitabilitas Perbankan Sebelum dan Sesudah Era Financial Technology Berkembang Pesat (Studi Empiris Pada Perusahaan Sub Sektor Perbankan Yang Terdaftar di Bursa Efek Indonesia Periode 2002-2017).

Astrini, Km. Suli, I Wayan Suwendra dan I Ketut Suwarna. (2018). Pengaruh CAR, LDR, dan Bank Size terhadap NPL pada Lembaga Perbankan yang Terdaftar di Bursa Efek Indonesia. Bisma: Jurnal Manajemen, Vol. 4.

https://journals.telkomuniversity.ac.id/jaf

E-ISSN 2581-1088 
Journal Accounting and Finance

Edisi Vol. 5, No. 2, September 2021

Universitas Telkom

Beck, T. and Levine, R. (2007). Finance, Inequality and the Poor. Washington: Journal of Economic Growth World Bank.

Bursa Efek Indonesia. (2020). Laporan Keuangan Perusahaan Terdaftar. www.idx.co.id diakses pada Agustus 2020.

Boot, A. W.A., 2017. The Future of Banking: From Scale \& Scope Economies to Fintech, European economy. Banks, regulation, and the real sector

Cessaria, Ruth Jannette. (2015). The Analysis of The Effect of Foreign Exchange Hedging, Interest Rate Hedging, and Commodity Hedging on Return on Invested Capital (ROIC) and Return on Asset (ROA) for Period 2010-2013. Jakarta: President University.

Christensen, Clayton M dan Joseph Power. (1995). Disruptive Technologies: Catching the Wave. Cambridge: Harvard Business Review.

Danang, Sunyoto. (2013). Metodologi Penelitian Akuntansi. Bandung: Refika Aditama Anggota Ikapi.

Dendawijaya, Lukman. (2009). Manajemen Perbankan. Jakarta: Ghalia Indonesia.

East Venture. (2020). East Ventures Digital Competitiveness Index (EV-DCI). Jakarta: Insight Report.

Gabor, D., dan Brooks, S. (2017). The Digital Revolution in Financial Inclusion: International Development in The Fintech Era. Bristol: University of The West of England.

Garvey, K. et al. (2017). The 2nd Asia Pacific Region Alternative Finance Industry Report Cultivating Growth (September). Cambridge Centre for Alternative Finance (CCAF). London : University of Cambridge.

Gitman, Lawrence J. dan Chad J. Zutter. (2012). Principles of Managerial Finance 13th Edition. Boston: Pearson

Hadad, Muliaman D. (2017). Financial Techonology (Fintech) di Indonesia. Jakarta: Otoritas Jasa Keuangan.

Hsueh \& Kuo, (2017). Effective Matching for P2P Lending by Mining Strong Association Rules. New York: ACM Press.

Iman, Nofie. (2018). Analisis Rasio Keuangan Perbankan Untuk Menilai Kinerja Keuangan Bank. (Studi Pada PT. Bank Mandiri (Persero), Tbk. yang Listing Di BEI Untuk Periode Tahun 2009- 2011). Jurnal Administrasi Bisnis (JAB)Vol. 1 No. 1

Kasmir. (2012). Analisis Laporan Keuangan. Jakarta : Raja Grafindo Persada

https://journals.telkomuniversity.ac.id/jaf

E-ISSN 2581-1088 
Kusuma, Ainia P. A. dan Deddy P. Koesrindartoto. (2014). Sustainability Practices and Financial Performance: An Empirical Evidence from Indonesia. Pattaya: International Conference on Trends in Economics

Nizar, Muhammad Afdi. (2017). Teknologi Keuangan (Fintech): Konsep dan Implementasinya di Indonesia. Muenchen: MPRA mpra.ub.uni-muenchen.de/98486.

Otoritas Jasa Keuangan. (2020). Statistik Perbankan Indonesia Volume 18. Diperoleh dari: https://www.ojk.go.id/id/kanal/perbankan/data-dan-statistik/statistik-perbankanindonesia/Documents/Pages/Statistik-Perbankan-Indonesia---Desember2019/SPI\%20Desember\%202019.pdf

Prastika, Yulia. (2019). Pengaruh Financial Technology (Fintech) Terhadap Profitabilitas Perbankan Syariah (Studi Komparasi Bank Syariah Mandiri, BNI Syariah, dan Bank Mega Syariah Periode 2016 - 2018). Lampung: Universitas Islam Negeri Raden Intan.

Puspitasari, Elen. (2019). Intellectual Capital Performance dan Return On Invested Capital pada Perusahaan Perbankan Indonesia. Semarang: LPPM Universitas Stikubank.

Rizvi, Kumail Abbas, Naqvi dan Tanveer. (2018). Is Pakistan Ready to Embrace Fintech Innovation?. The Lahore Journal of Economics.

Shellsea, Ivana. (2019). Analisis Perbandingan Rasio Profitabilitas Bank Konvensional Yang Terdaftar Dalam Bursa Efek Indonesia Sebelum dan Sesudah Adanya Online Peer To Peer Lending.

Sinambela, Elizar dan Rohani. (2017). Pengaruh Penyediaan Layanan Internet Banking Terhadap Kinerja Keuangan Perbankan di Bursa Efek Indonesia. Forum Keuangan dan Bisnis Indonesia.

Subramanyam, K.R. dan John J. Wild. (2010). Analisis Laporan Keuangan Edisi 10. Jakarta: Salemba Empat. 